\title{
Trudne początki. Organizacja Sądu Okręgowego w Zielonej Górze w pierwszych latach po zakończeniu II wojny światowej ${ }^{1}$
}

I. Przed 1945 r. organizację sądownictwa na obszarach przyłączonych do Polski po zakończeniu II wojny światowej określała pruska ustawa z 27 stycznia 1877 r. o organizacji sądownictwa.W Zielonej Górze funkcjonował wówczas jedynie sąd obwodowy ${ }^{2}$ jako sąd pierwszej instancji. Sądem drugiej instancji dla spraw rozpoznawanych przez zielonogórski sąd obwodowy był Sąd Krajowy w Głogowie. Obejmował on swoją właściwością terytorialną powiaty głogowski, zielonogórski, wschowski, żagański, szprotawski, górowski, ścinawski ${ }^{3}$. Sądem wyższego rzędu dla głogowskiego sądu krajowego był Wyższy Sąd Krajowy we Wrocławiu 4 .

Po zakończeniu działań wojennych i przyłączeniu tych obszarów do państwa polskiego rozpoczęto budowę polskiego wymiaru sprawiedliwości. Ostatecznie na obszarze dzisiejszego województwa lubuskiego powołano do życia trzy sądy okręgowe: w Gorzowie Wielkopolskim, Zielonej Górze oraz w Głogowie z siedzibą w Nowej Soli 5 .

${ }^{1}$ Artykuł powstał w ramach projekt sfinansowanego ze środków Narodowego Centrum Nauki przyznanych na podstawie decyzji numer DEC-2013/09/N/HS5/00674.

2 Szerszą analizę działalności niemieckich sądów obwodowych w latach 1879-1945 przedstawił H. Niestój, Sąd obwodowy w strukturze sądownictwa niemieckiego. Ustrój sądów na Śląsku od czasów habsburskich do 1945 r. Struktury i zasady funkcjonowania sądu obwodowego. Problemy metodologiczne opracowania zespolów akt sądowych, „Archnet. Naukowy Portal Archiwalny” [dostęp 2.08.2015 r.].

${ }^{3}$ Gesetz, betreffend die Errichtung der Oberlandesgerichte und der Landgerichtevom 4. März 1878, „Gesetz-Sammlung für die Königlichen Preussischen Staaten”, 1878 (19. März), nr 12, s. 116.

${ }^{4}$ Ibidem, s. 115.

${ }^{5}$ Błędnie zatem podaje E. Ozga-Świetlik w artykule Zarys Historii Lubuskiego Wymiaru Sprawiedliwości, „Studia Zielonogórskie”, nr 11, s. 149-159, że tuż po zakończeniu drugiej wojny światowej na obszarze tzw. Ziemi Lubuskiej działały dwa sądy okręgowe - w Gubinie oraz w Głogowie. 
Sądy te formalnie powołano na mocy rozporządzenia ministra sprawiedliwości z 15 czerwca 1949 r. o utworzeniu Sądów Apelacyjnych w Białymstoku, Gdańsku, Kielcach, Łodzi, Olsztynie, Rzeszowie, Szczecinie i Wrocławiu oraz o ustaleniu okręgów Sądów Apelacyjnych ${ }^{6}$. Faktycznie funkcjonowały one jednak już znacznie wcześniej, od drugiej połowy 1945 r. Wyszczególniono je bowiem w spisie sądów i prokuratur Rzeczypospolitej, opublikowanym w „Dzienniku Urzędowym Ministerstwa Sprawiedliwości” z 1 grudnia 1945 r. ${ }^{7}$

Pierwsze działania mające na celu budowę struktur polskiego sądownictwa w Zielonej Górze podjęto już w czerwcu 1945 r. Wówczas to przybył do miasta sędzia Ignacy Kozłowski, jednak z uwagi na incydent z szabrownikami wrócił niebawem do Poznania ${ }^{8}$. Pierwotnie planowano w Zielonej Górze utworzenie jedynie wydziału zamiejscowego Sądu Okręgowego w Gorzowie Wielkopolskim bądź w Poznaniu9. Wydział ten miał obejmować swoją właściwością miejscową okręgi sądów grodzkich w Gubinie, Krośnie Odrzańskim, Sulechowie, Zielonej Górze i Konotopie ${ }^{10}$. Obsadę kadrową wydziału zamiejscowego miało stanowić trzech sędziów oraz sekretariat wydziału ${ }^{11}$. Jak się wydaje, powołanie w Zielonej Górze wydziału zamiejscowego sądu poznańskiego bądź gorzowskiego nie wykroczyło poza sferę planów, choć we współczesnej literaturze wyrażono również stanowisko, iż do 2 listopada 1945 r. zielonogórski sąd funkcjonował jako wydział zamiejscowy Sądu Okręgowego w Poznaniu ${ }^{12}$.

II. Zielonogórski sąd okręgowy obejmował swoją właściwością okręgi sądów grodzkich w Gubinie, Krośnie Odrzańskim, Świebodzinie i Zielonej Górze $^{13}$. Nie uruchomiono sądu grodzkiego w Konotopie, a siedzibą sądu grodzkiego obejmującego właściwością powiat sulechowsko-świebodziński został Świebodzin, a nie jak wcześniej planowano - Sulechów. Okręg Sądu Okręgowego w Zielonej Górze obejmował zatem centralną część dzisiejszej ziemi lubuskiej.

${ }^{6}$ Dz. U. 1949 r., nr 36, poz. 270.

7 Spis sadów i prokuratur Rzeczypospolitej, „Dziennik Urzędowy Ministerstwa Sprawiedliwości”, 1945, nr 1 s. 16.

${ }^{8}$ T. Dzwonkowski, Powiat zielonogórski w latach 1945-1948. Zarys dziejów politycznych, Warszawa 1997, s. 48.

${ }^{9}$ Sprawozdanie Józefa Stachurskiego delegata do spraw organizacji sądownictwa polskiego w Zielonej Górze z 12.08.1945 r., Archiwum Państwowe w Zielonej Górze [dalej jako AP ZG], sygn. Akt 89/433/24, k. 2.

${ }^{10}$ Ibidem.

11 Ibidem.

12 R. Zaradny, Władza i spoleczność Zielonej Góry w latach 1945-1975, Zielona Góra 2009, s. 247.

$13 \S 60$ rozporządzenia ministra sprawiedliwości z 15 czerwca 1949 roku o utworzeniu Sądów Apelacyjnych w Białymstoku, Gdańsku, Kielcach, Łodzi, Olsztynie, Rzeszowie, Szczecinie i Wrocławiu oraz o ustaleniu okręgów Sądów Apelacyjnych, Dz. U. 1949 r., nr 36, poz. 270. 
Największym miastem na tym obszarze była Zielona Góra licząca wówczas 15788 mieszkańców ${ }^{14}$. Niemniej w mieście tym następował szybki przyrost mieszkańców i już 31 sierpnia 1947 r. liczyło ono 31889 mieszkańców ${ }^{15}$. Większość stanowili przybysze z obszaru Wielkopolski, z kolei przesiedleńcy z dawnych województw wschodnich stanowili 30\% ogółu mieszkańców Zielonej Góry w tym okresie ${ }^{16}$.

Kolejnym miastem leżącym na obszarze właściwości miejscowej zielonogórskiego sądu okręgowego było Krosno Odrzańskie. Zamieszkiwały je wówczas 2244 osoby ${ }^{17}$. Na marginesie warto zwrócić uwagę, że siedzibą sądu grodzkiego w powiecie krośnieńskim zostało Krosno Odrzańskie, a nie Zemsz (obecnie Lubsko), które wówczas nie tylko było większą miejscowością, ale także posiadało doskonałą infrastrukturę - nowoczesny budynek sądowy $\mathrm{i}$ areszt ${ }^{18}$. Powstający w Krośnie Odrzańskim sąd grodzki borykał się zaś z problemami lokalowymi z uwagi na zniszczenie w czasie wojny poniemieckiego budynku sądowego ${ }^{19}$. W okręgu zielonogórskiego sądu znajdowały się również Gubin liczący 3040 mieszkańców, a także Świebodzin - 6144 mieszkańców ${ }^{20}$.

Jednym z poważnych utrudnień, jakie pojawiały się w trakcie budowy struktur polskiego sądownictwa na tym obszarze, był brak sprawnej komunikacji między siedzibą sądu okręgowego a miastami będącymi siedzibami sądów grodzkich wchodzących w skład okręgu zielonogórskiego sądu okręgowego. Wacław Słonimski, sędzia Sądu Apelacyjnego w Poznaniu, który przeprowadzał wizytacje Sądu Okręgowego w Zielonej Górze, podkreślił w jednym z protokołów powizytacyjnych, że Zielona Góra posiada dogodną komunikację kolejową i autobusową z Poznaniem, jednak połączenia kolejowe z Krosnem, Gubinem i Świebodzinem są utrudnione, w zasadzie nie było możliwości odbycia podróży koleją z Zielonej Góry do tych miejscowości i z powrotem $w$ ciągu jednego dnia ${ }^{21}$.

Sąd Okręgowy w Zielonej Górze do 1950 r. należał do okręgu Sądu Apelacyjnego w Poznaniu. Wraz z utworzeniem Sądu Apelacyjnego w Zielonej

${ }^{14}$ Powszechny sumaryczny spis ludności z dnia 14 lutego 1946 r., Warszawa 1947, tabela nr 3, s. 51 .

${ }^{15}$ H. Kurowska, Liczba mieszkańców Zielonej Góry w latach 1945-2010, „Studia Zachodnie", 2013, t. 15 , s. 145.

${ }^{16}$ Ibidem, s. 146.

17 Powszechny sumaryczny spis ludności..., s. 47.

18 Pismo kierownika Sądu Grodzkiego w Krośnie Odrzańskim do Prezesa Sądu Okręgowego w Zielonej Górze z 16.08.1947 r., AP ZG, sygn. Akt 89/433/24, k. 168.

${ }_{19}$ Sprawozdanie sędziego Stachurskiego do sędziego Sądu Apelacyjnego w Poznaniu T. Krycha z 12.08.1945 r., AP ZG, sygn. Akt 89/433/24, k. 2.

${ }^{20}$ Powszechny sumaryczny spis ludności..., s. 47-50.

${ }^{21}$ Protokół drugiej wizytacji Sądu Okręgowego w Zielonej Górze przeprowadzonej w dniach 2-7 czerwca 1947 roku przez sędziego Sądu Apelacyjnego w Poznaniu W. Słonimskiego, sygn. akt AP ZG 89/433/28, k. 25. 
Górze w lipcu 1950 r. włączono go do okręgu tego nowo powołanego sądu apelacyjnego $^{22}$.

III. W zespole Sądu Okręgowego w Zielonej Górze zachowały się nieliczne akta prezydialne. Wśród nich przetrwały m.in. protokoły wizytacji sądu z lat 1946-1948. Jest to cenne źródło, które umożliwia odtworzenie organizacji sądu na przestrzeni trzech tużpowojennych lat, a także pozwala na ustalenie wpływu spraw cywilnych i karnych.

W maju 1946 r. w Sądzie Okręgowym w Zielonej Górze pracowało dwóch sędziów okręgowych - Józef Stachurski i Stanisław Matczyński oraz sędzia grodzki Wiktor Dmoszyński, delegowany do Sądu Okręgowego 23. Obsadę kadrową uzupełniało dziewięciu urzędników sądowych, dwóch woźnych i kierowca. Zauważyć przy tym trzeba, że planowaną pełną obsadę kadrową zielonogórskiego sądu okręgowego określono na sześciu sędziów w tym etat prezesa, etat wiceprezesa, trzy etaty sędziów i jeden etat sędziego śledczego, ponadto planowano obsadzenie dziesięciu etatów urzędniczych i dwóch etatów szoferów ${ }^{24}$. Nie obsadzono więc wówczas stanowisk prezesa, wiceprezesa i jednego stanowiska sędziowskiego. Funkcję pełniącego obowiązki prezesa sprawował sędzia Józef Stachurski.

W kolejnym roku funkcjonowania zielonogórskiego sądu zwiększyła się jego obsada kadrowa, choć w dalszym ciągu nie został powołany prezes sądu. Jego obowiązki pełnił wówczas sędzia S. Matczyński ${ }^{25}$. Wiceprezesem sądu był J. Stachurski, a stanowiska sędziowskie zajmowali Kazimierz Drzewiecki, który jednak nie podjął służby w Sądzie Okręgowym w Zielonej Górze, gdyż decyzją ministerstwa sprawiedliwości delegowano go do pełnienia obowiązków sędziego grodzkiego we Wrześni, W. Dmoszyński, który z uwagi na stan zdrowia w 1947 r. nie orzekał, Alojzy Kużdowicz i Władysław Fiebig ${ }^{26}$. Ponadto w zielonogórskim sądzie pracowało jeszcze czternastu urzędników i dwóch woźnych.

Zgodnie z rozdzielnikiem ministerstwa sprawiedliwości na 1946 r. liczba etatów przydzielonych do Sądu Okręgowego w Zielonej Górze przedstawiała się następująco - jeden etat prezesa sądu, dwa etaty wiceprezesów, cztery etaty

$22 \S 10$ pkt. a rozporządzenia Ministra Sprawiedliwości z 6 lipca 1950 roku o utworzeniu Sądów Apelacyjnych w Koszalinie, Opolu i Zielonej Górze oraz o ustaleniu okręgów Sądów Apelacyjnych w Bydgoszczy, Katowicach, Kielcach, Łodzi, Olsztynie, Poznaniu i Warszawie, Dz. U. 1950 r., nr 28, poz. 265.

${ }^{23}$ Protokół wizytacji Sądu Okręgowego w Zielonej Górze przeprowadzonej w dniach 20.05.25.05.1946 r. przez sędziego sądu apelacyjnego W. Słonimskiego na polecenie prezesa Sądu Apelacyjnego w Poznaniu, AP ZG, sygn. Akt 89/433/28, k. 2.

24 Ibidem, k. 2.

25 Protokół drugiej wizytacji Sądu Okręgowego w Zielonej Górze przeprowadzonej w dniach 2-7 czerwca 1947 roku, k. 24.

26 Protokół drugiej wizytacji Sądu Okręgowego w Zielonej Górze przeprowadzonej w dniach 2-7 czerwca 1947 roku, k. 26. 
sędziów okręgowych, jeden sędzia okręgowy śledczy, szesnastu urzędników, czterech woźnych. W czerwcu 1947 r., podobnie jak rok wcześniej, nie obsadzono wszystkich etatów przewidzianych dla zielonogórskiego sądu. Przede wszystkim nie obsadzono etatu wiceprezesa sądu. Zauważyć również trzeba, że faktycznie w zielonogórskim sądzie pracowało jedynie czterech, a nie sześciu sędziów. K. Drzewiecki, jak to wspomniano powyżej, został delegowany do Sądu Grodzkiego we Wrześni, a W. Dmoszyński nie podejmował swoich obowiązków z uwagi na stan zdrowia. Nadal nie obsadzono również etatu sędziego śledczego. W 1948 r. po raz kolejny doszło do zmian w obsadzie kadrowej zielonogórskiego sądu okręgowego. Funkcję pełniącego obowiązki prezesa sprawował nadal sędzia S. Matczyński. Nieobsadzone pozostawały stanowiska wiceprezesów ${ }^{27}$. Poza p.o. prezesa w Sądzie Okręgowym w Zielonej Górze pracowali w tym czasie sędziowie Jan Meysner, A. Kużdowicz, W. Fiebig, Edmund Wierzchowski, Alfons Lisewski. Zaznaczyć trzeba, że E. Wierzchowski został powołany decyzją ministerstwa sprawiedliwości do pełnienia funkcji sędziego sądu okręgowego tylko na okres jednego roku ${ }^{28}$. Zgodnie z rozdzielnikiem ministerstwa sprawiedliwości na $1948 \mathrm{r}$. nieobsadzony pozostawał jeden etat sędziowski, nie wybrano również w dalszym ciągu sędziego śledczego ${ }^{29}$. Obsada urzędnicza wynosiła dwunastu urzędników, trzech woźnych i jednego szofera, wszystkie etaty urzędnicze w 1948 r. były obsadzone.

Nieobsadzenie stanowiska sędziego śledczego w zielonogórskim sądzie okręgowym mogło być spowodowane nie tylko brakami kadrowymi, ale również świadomą polityką władz. Instytucja sędziego śledczego była bowiem stopniowo likwidowana w powojennym ustawodawstwie karnym. W postępowaniu w sprawach o przestępstwa szczególnie niebezpieczne w okresie odbudowy państwa, wprowadzonym na mocy dekretu z 16 listopada 1945 r. o przestępstwach szczególnie niebezpiecznych w okresie odbudowy państwa, zlikwidowano instytucję sędziego śledczego, a jego kompetencje przejął prokurator. Rozwiązanie to zostało utrzymane w dekrecie z 13 czerwca $1946 \mathrm{r}$. o tym samym tytule, czyli w tzw. małym kodeksie karnym. Następnie przyjęto je w ustawie z 27 kwietnia 1949 r. o zmianie przepisów postępowania karnego ${ }^{30}$. Wraz z wejściem w życie tej nowelizacji, w dniu 1 lipca $1949 \mathrm{r}$. nastąpiła całkowita likwidacja instytucji sędziego śledczego zarówno w postępowaniu powszechnym, jak i w postępowaniach szczególnych.

27 Protokół trzeciej wizytacji Sądu Okręgowego w Zielonej Górze przeprowadzonej w dniach 2-5 listopada 1948 roku, sygn. akt AP ZG 89/433/28, k. 89.

${ }^{28}$ Ibidem, k. 89. Podstawę do powołania przez ministra sprawiedliwości osoby legitymującej się wykształceniem prawniczym do pełnienia funkcji sędziowskich przez jeden rok był art. $5 \mathrm{i}$ art. 5 dekretu z 22 lutego 1946 r. o rejestracji i przymusowym zatrudnianiu we władzach wymiaru sprawiedliwości osób, mających kwalifikacje do objęcia stanowiska sędziowskiego, Dz. U. 1946 r., nr 9, poz. 65 .

29 Protokół trzeciej wizytacji Sądu Okręgowego w Zielonej Górze..., k. 89.

${ }^{30}$ Dz. U. z 1949 r., nr 32, poz. 238. 
IV. Nowelizacja art. 121 prawa o ustroju sądów powszechnych z dnia 14 marca 1945 r. zniosła zakaz przynależności sędziów do partii politycznych $^{31}$. Z tego też względu w Sądzie Okręgowym w Zielonej Górze działały partie polityczne. Utworzono koła sądowe Polskiej Partii Robotniczej, Polskiej Partii Socjalistycznej i Stronnictwa Demokratycznego ${ }^{32}$. Do partii tych należeli zarówno sędziowie, jak i urzędnicy. Prominentnym działaczem Stronnictwa Demokratycznego był sędzia J. Stachurski ${ }^{33}$. Prężnie działało również Towarzystwo Przyjaźni Polsko-Radzieckiej, do którego należeli wszyscy pracownicy sądu, a przewodził mu wiceprezes zielonogórskiego sądu okręgowego S. Matczyński ${ }^{34}$.

Przynależność sędziów do partii politycznych i organizacji o charakterze quasi-politycznym nie była wówczas niczym nadzwyczajnym. Wręcz przeciwnie, stanowiło to spełnienie pewnych oczekiwań ówczesnych władz. Wiceminister sprawiedliwości Leon Chajn uzasadniał przynależność sędziów do partii politycznych stwierdzając, że ,nie ma apolitycznych ludzi dojrzałych"35. Zauważał również, iż przedwojenna regulacja zabraniająca sędziom udziału w życiu politycznym była ,wynikiem zakłamania i tendencją do bałamucenia społeczeństwa"36. Z kolei pierwszy prezes Sądu Najwyższego, Wacław Barcikowski, podkreślał, że regulacja zakazująca sędziom członkostwa w partiach politycznych miała na celu oderwanie sędziów od społeczeństwa oraz przeszkodzanie sędziom w brataniu się z ludem, poznawaniu jego potrzeb i krzywd ${ }^{37}$.

V. Sąd Okręgowy w Zielonej Górze zajmował budynek, w którym mieścił się również Sąd Grodzki w Zielonej Górze oraz Prokuratura Sądu Okręgowego w Zielonej Górze. Do dyspozycji zielonogórskiego sądu okręgowego pozostawało osiem pokoi, dwie sale rozpraw, w tym jedna wspólna z sądem grodzkim oraz salka narad ${ }^{38}$. Sędzia wizytator podkreślał, że wyposażenie sądu jest skromne, choć budynek jest schludny i utrzymany w należytej czystości. Niemniej zauważał, że wymagał on gruntownego remontu, przede wszystkim wymiany drzwi oraz okien ${ }^{39}$.

31 Dekret z dnia 14 marca 1945 r. o zmianie prawa o ustroju sąów powszechnych, Dz. U. 1945 r., nr 9, poz. 46.

32 Protokół trzeciej wizytacji Sądu Okręgowego w Zielonej Górze..., k. [b.p.a.].

33 T. Dzwonkowski, op. cit., s. 65.

34 Protokół trzeciej wizytacji Sądu Okręgowego w Zielonej Górze..., k. [b.p.a.].

35 L. Chajn, Na przełomie dwóch lat, „Demokratyczny Przegląd Prawniczy”, 1948, nr 1, s. 7.

36 Ibidem, s. 7.

37 W. Barcikowski, Demokracja a sądownictwo, „Demokratyczny Przegląd Prawniczy”, 1946, nr 5-6, s. 9.

38 I Protokół wizytacji Sądu Okręgowego w Zielonej Górze przeprowadzonej..., k. 6.

39 Pismo p.o. prezesa Sądu Okręgowego w Zielonej Górze S. Matczyńskiego do ministerstwa sprawiedliwości z 7.08.1946 r., sygn. akt AP ZG 89/433/24, k. 55. 
$\mathrm{Na}$ trudną sytuację materialną sądu wskazuje również brak w 1946 r. biblioteki sądowej, a także Dzienników Ustaw i Dzienników Urzędowych z lat 1918-1939. Bez wątpienia znacznie utrudniało to normalne urzędowanie zielonogórskiego sądu. Bibliotekę sądową utworzono dopiero w 1947 r. Składała się ona jednak głównie z książek w języku niemieckim. Było to około tysiąca tomów. Książki polskojęzyczne były przechowywane w sekretariacie prezydialnym w przeznaczonej do tego celu szafie ${ }^{40}$. Nadal jednak brakowało kompletów Dzienników Ustaw Rzeczypospolitej. Dopiero w 1948 r. poprawił się stan sądowego księgozbioru. Nie odnotowano już braku Dzienników Ustaw. W dalszym ciągu nie skatalogowano jednak poniemieckiej biblioteki prawniczej, którą częściowo przechowywano w sali rozpraw, a częściowo w jednym z pokojów urzędniczych ${ }^{41}$. Od listopada $1947 \mathrm{r}$. funkcjonowała również W zielonogórskim sądzie okręgowym czytelnia. Prenumerowano nie tylko czasopisma prawnicze, ale także np. „Głos Wielkopolski” czy „Robotnika”42.

W trudnym powojennym okresie dbano również o odpowiednie wyżywienie pracowników sądu. W początkach czerwca 1947 r. uruchomiono bowiem stołówkę sądową. Wcześniej, do momentu jej uruchomienia, pracownikom sądu wydawano tylko kawę i dwie suche bułki ${ }^{43}$. Sąd dysponował w omawianym okresie także skromnym parkiem samochodowym. Była to półciężarówka „Gaz” oraz samochód osobowy marki „Opel”44. Jak się wydaje, samochody służbowe pozwalały na w miarę dogodną komunikację m.in. z miastami, w których znajdowały się siedziby sądów grodzkich, należące do właściwości terytorialnej Sądu Okręgowego w Zielonej Górze.

VI. W ramach kontaktu sądownictwa ze społeczeństwem prowadzono w zielonogórskim okręgu sądowym działania z zakresu popularyzacji prawa. Przy wszystkich sądach grodzkich w okręgu powołano komisje popularyzacji prawa. Przewodniczącym takiej komisji działającej przy Sądzie Grodzkim w Zielonej Górze był prezes Sądu Okręgowego, członkami komisji byli zaś sędziowie, prokuratorzy, przedstawiciele adwokatury, inspektoratu szkolnego, partii politycznych, rad narodowych, a także organizacji społecznych i rad zakładowych ${ }^{45}$. Było to zatem gremium skupiające przedstawicieli różnych środowisk ówczesnej Zielonej Góry.

W ramach tych działań w okresie od 1 stycznia 1947 r. do 1 listopada 1948 r. wygłoszono sto dwadzieścia dwa referaty dotyczące różnego rodza-

40 Ibidem, k. [b.p.a.].

${ }^{41}$ Protokół III wizytacji Sądu Okręgowego w Zielonej Górze..., k. 99.

${ }^{42}$ Ibidem, k. [b.p.a.].

${ }^{43}$ Ibidem, k. [b.p.a.].

44 Protokół drugiej wizytacji Sądu Okręgowego w Zielonej Górze przeprowadzonej w dniach 2-7 czerwca 1947 roku..., k. [b.p.a.].

45 Protokół trzeciej wizytacji Sądu Okręgowego w Zielonej Górze przeprowadzonej..., k. 94. 
ju zagadnień prawnych ${ }^{46}$. Prelegentami byli głównie sędziowie, prokuratorzy oraz aplikanci sądowi. Na uwagę zasługuje fakt, że aż pięćdziesiąt referatów wygłoszono w zakładach pracy, a pięćdziesiąt jeden spotkań popularyzujących prawo odbyło się na wsiach ${ }^{47}$. W zasobie archiwalnym Archiwum Państwowego w Zielonej Górze nie zachowały się niestety teksty wygłoszonych referatów.

Spotkania popularyzatorskie prowadzone przez sędziów zielonogórskiego sądu były konieczne z uwagi na przeprowadzoną w latach 1945-1946 unifikację prawa cywilnego. Jako pierwsze zostało zunifikowane dekretem z 29 sierpnia 1945 r. prawo osobowe ${ }^{48}$, następnie dekretem z 25 września 1945 r. małżeńskie prawo osobowe ${ }^{49}$. Do końca 1946 r. wydano dziesięć dekretów unifikujących prawo cywilne. We współczesnej literaturze zauważa się, że nowe prawo cywilne stało na dobrym poziomie merytorycznym ${ }^{50}$. Jak się wydaje, nie bez znaczenia dla oceny działań popularyzujących wiedzę na temat prawa był fakt, że na tzw. Ziemie Odzyskane przybywały osoby żyjące uprzednio na obszarach obowiązywania różnych systemów prawnych.

Działalność popularyzatorska wynikała przede wszystkim z odgórnych nakazów płynących z ministerstwa sprawiedliwości. Okólnik ministra sprawiedliwości nr 50/NS/45 w Sprawie kontaktu sądów ze społeczeństwem nakazywał nie tylko organizowanie spotkań popularyzujących prawo, ale także m.in. uczestnictwo sądów i prokuratur w akacji siewnej i żniwnej ${ }^{51}$.

VII. W początkowym okresie swojej działalności sąd składał się z wydziału karnego, wydziału cywilnego oraz z wydziału rejestrowego ${ }^{52}$. Przewodniczącym wydziału karnego był sędzia S. Matczyński, w wydziale tym oprócz niego orzekali również sędziowie J. Stachurski, W. Dmoszyński, a także okazjonalnie kierownik Sądu Grodzkiego w Zielonej Górze, sędzia Pawlicki ${ }^{33}$. Warto zauważyć, że w początkowym okresie funkcjonowania sądu nie powołano odrębnego wydziału do rozpoznawania spraw doraźnych. Jedynie w ramach wydziału karnego funkcjonował sąd doraźny, któremu przewodniczył S. Matczyński.

Warto przypomnieć, że początkowo w postępowaniu doraźnym, zgodnie $\mathrm{z}$ art. 1 dekretu z dnia 16 listopada 1945 r. o postępowaniu doraźnym ${ }^{54}$, były rozpoznawane sprawy o zbrodnie określone w rozdziale XXXIII kodeksu kar-

46 Ibidem, k. [b.p.a.].

47 Ibidem, k. [b.p.a.].

48 Dz. U. 1945 r., nr 40, poz. 223.

49 Dz. U. 1945 r., nr 45, poz. 270.

50 A. Lityński, Historia prawa Polski Ludowej, Warszawa 2005, s. 185.

51 Okólnik ministra sprawiedliwości nr 50/NS.45 w sprawie kontaktu sadów ze spoleczeństwem, „Dziennik Urzędowy Ministerstwa Sprawiedliwości”, 1945, nr 1 s. 10.

52 Protokół wizytacji Sądu Okręgowego w Zielonej Górze przeprowadzonej w dniach 20.05.-25.05 .1946 r..., k. 3 .

53 Ibidem, k. 8.

54 Dz. U. 1945 r., nr 53, poz. 301. 
nego z 1932 r., obejmującym przestępstwa polegające na sprowadzeniu niebezpieczeństwa powszechnego, zabójstwo, kradzież i przywłaszczenie, o ile sprawca dopuścił się tych przestępstw na szkodę państwa, samorządu, instytucji prawa publicznego, przedsiębiorstwa państwowego, samorządowego albo znajdującego się pod zarządem państwowym lub samorządowym bądź organizacji społecznej o znaczeniu ogólnopaństwowym, a także w stosunku do mienia będącego przedmiotem przewozu publicznymi środkami komunikacji bądź znajdującego się $\mathrm{w}$ pomieszczeniach lub urządzeniach związanych $\mathrm{z}$ ruchem tych środków komunikacji. Ponadto przestępstwo kradzieży lub przywłaszczenia było rozpoznawane $\mathrm{w}$ trybie doraźnym, jeśli sprawca przy jego popełnieniu posłużył się bronią lub podstępnie podawał się za urzędnika. Dekret przewidywał, że w trybie doraźnym rozpoznawane były również sprawy o takie przestępstwa, jak kradzież rozbójnicza, rozbój oraz przestępstwa urzędnicze z art. $286 \S 1$ i 2 k.k., łapownictwo z art. 290 k.k. oraz typy czynów zabronionych określonych w art. 22, 23 i 29 dekretu o przestępstwach szczególnie niebezpiecznych w okresie odbudowy państwa z dnia 16 listopada $1945 \mathrm{r}$.

W pierwszych latach działalności zielonogórskiego sądu nie utworzono również odrębnego wydziału rozpoznającego sprawy o przestępstwa szczególnie niebezpieczne w okresie odbudowy państwa, choć konieczność powołania takiego wydziału przewidywał art. 35 ust. 4 dekretu o przestępstwach szczególnie niebezpiecznych w okresie odbudowy państwa z 16 listopada $1945 \mathrm{r}^{55}$ Było to zapewne spowodowane niewielkim wpływem tego rodzaju spraw w pierwszych miesiącach $1946 \mathrm{r}$.

Zwraca również uwagę nieliczna obsada kadrowa sekretariatu wydziału karnego. Kierował nim Michał Mikulski, który jedynie okazjonalnie korzystał z pomocy praktykanta Władysława Nawrockiego ${ }^{56}$. W lipcu 1946 r. zwiększono obsadę sekretariatu tego wydziału, przesuwając do pracy w wydziale karnym O. Rytarowską, dotychczas pracującą w sekretariacie wydziału cywilnego ${ }^{57}$. Zwrócono się również do ministerstwa sprawiedliwości z prośbą o udzielenie odpowiednich kredytów na zakup Dzienników Ustaw z lat 1918-1939 ${ }^{58}$.

Posiedzenia sądu w sprawach karnych odbywały się - w zależności od wpływu spraw karnych - raz lub dwa razy na tydzień, a na jedno posiedzenie wyznaczano od ośmiu do dziesięciu spraw ${ }^{59}$. Jako ciekawostkę warto podać, że posiedzenia latem rozpoczynały się o godzinie 8.00 rano, natomiast zimą o godzinie 9.00 .

55 Dz. U. 1945 r., nr 3, poz. 300.

56 Protokół wizytacji Sądu Okręgowego w Zielonej Górze przeprowadzonej w dniach 20.05.25.05.1946 r., k. 8 .

57 Pismo p.o. prezesa Sądu Okręgowego w Zielonej Górze do prezesa Sądu Apelacyjnego w Poznaniu z 9 września 1946 roku, sygn. akt AP ZG 89/433/28, k. 17.

58 Ibidem, k. 18

59 Protokół wizytacji Sądu Okręgowego w Zielonej Górze przeprowadzonej w dniach 20.05.-25.05 .1946 r., k. 9. 
Przeprowadzający wizytację sędzia Sądu Apelacyjnego w Poznaniu, W. Słonimski, dobrze ocenił poziom orzecznictwa wydziału karnego Sądu Okręgowego w Zielonej Górze. Podkreślił, że na siedem spraw dotychczas skierowanych do sądu drugiej instancji powróciła jedna sprawa, w której sąd wyższej instancji zatwierdził orzeczenie zielonogórskiego sądu.

Kolejnym wydziałem istniejącym od początku funkcjonowania Sądu Okręgowego w Zielonej Górze był, jak wspomniano, wydział cywilny. Przewodniczącym tego wydziału był J. Stachurski, a orzekali w nim także sędziowie S. Matczyński i W. Dmoszyński ${ }^{60}$. W sekretariacie wydziału cywilnego były zatrudnione dwie osoby - kierownik Józef Partyka oraz O. Rytarowska $^{61}$.

W wydziale rejestrowym orzekał sędzia S. Matczyński, w sekretariacie pracował kierownik sekretariatu wydziału cywilnego J. Partyka ${ }^{62}$. W rejestrze spółdzielni do maja $1946 \mathrm{r}$. wpisano trzydzieści cztery sprawy, a w rejestrze handlowym - dział „A” zarejestrowano jedną firmę, przy czym dla prowadzenia tego rejestru zużytkowano księgę niemiecką.

W 1947 r. w Sądzie Okręgowym w Zielonej Górze nadal funkcjonowały dwa wydziały. Wydział karny, doraźny i dla przestępstw szczególnie niebezpiecznych w okresie odbudowy państwa, jego przewodniczącym był S. Matczyński. Obsadę kadrową sekretariatu wydziału karnego stanowiło pięć osób. Drugim wydziałem był wydział cywilny z sekcją rejestrową ${ }^{63}$. Przewodniczącym wydziału cywilnego był J. Stachurski. W sekretariacie tego wydziału pracowało trzech urzędników.

W listopadzie 1948 r. funkcjonowało w Sądzie Okręgowym w Zielonej Górze już pięć wydziałów: I cywilny, II karny ogólny, III karno-skarbowy, IV doraźny i wydział V dla przestępstw szczególnie niebezpiecznych w okresie odbudowy państwa ${ }^{64}$. Przewodniczącym wydziału I cywilnego był Jan Meysner, wydziałowi II karnemu ogólnemu przewodniczył W. Fiebig, wydziałowi III karno-skarbowemu Edward Wierzchowski, przewodniczącym wydziału IV doraźnego był S. Matczyński, a wydziału V dla spraw szczególnie niebezpiecznych w okresie odbudowy państwa - A. Kużdowicz ${ }^{65}$.

Bez wątpienia znakiem czasów była dominacja wydziałów karnych. Ponadto podkreślić trzeba, że wydziały karno-skarbowy, doraźny oraz dla spraw szczególnie niebezpiecznych w okresie odbudowy państwa były obsadzone tylko przez jednego sędziego ${ }^{66}$. W skład kompletów orzekających w sprawach

\footnotetext{
60 Ibidem, k. 10.

61 Ibidem, k. 10.

62 Ibidem, k. 11.

63 Ibidem, k. [b.p.a.].

64 Protokół trzeciej wizytacji Sądu Okręgowego w Zielonej Górze..., k. 90.

65 Ibidem, k. 90-91.

66 Ibidem, k. 90-91.
} 
doraźnych oraz szczególnie niebezpiecznych w okresie odbudowy państwa wchodzili również ławnicy.

Wydziały karne orzekały nie tylko w siedzibie sądu, lecz również na posiedzeniach wyjazdowych w Gubinie, Krośnie Odrzańskim i Świebodzinie ${ }^{67}$. Praktyka taka spowodowana była zapewne koniecznością szybszego rozpoznawania spraw wpływających z terenów pogranicza, a także wspominanymi już trudnościami komunikacyjnymi między poszczególnymi miastami leżącymi na obszarze właściwości miejscowej Sądu Okręgowego w Zielonej Górze, co z pewnością utrudniało dotarcie do sądu świadkom czy pokrzywdzonym.

Wraz z krzepnięciem polskiego sądownictwa na ziemiach zachodnich wzrastał również wpływ spraw do zielonogórskiego sądu okręgowego. O ile w repertorium K odnotowano za $1945 \mathrm{r}$. wpływ trzech spraw, a za okres od 1 stycznia 1946 r. do 20 maja 1946 r. wpływ trzydziestu spraw, to już w 1947 r. w repertorium tym odnotowano wpływ trzystu czternastu spraw, a w 1948 r. trzystu trzydziestu dziewięciu spraw ${ }^{68}$. W 1947 r. najwięcej spraw dotyczyło przestępstwa nielegalnego pędzenia alkoholu - skazano za ten czyn dwieście osiemdziesiąt dwie osoby, co stanowiło prawie $40 \%$ skazań $^{69}$. W 1948 r. jednak liczba skazań za ten czyn znacznie spadła. Skazano tylko sześćdziesiąt trzy osoby. Znacznie za to wzrosła w stosunku do 1947 r. liczba skazań za przestępstwo szabrownictwa $\mathrm{z}$ art. 43 m.k.k. O ile w 1947 r. za szaber skazano dwadzieścia siedem osób, to w $1948 \mathrm{r}$. już sto dwadzieścia sześćc ${ }^{70}$.

W 1947 r. nie skazano żadnej osoby za czyn z art. 44 m.k.k., tj. wywóz mienia z Ziem Odzyskanych. W następnym roku skazań za ten czyn było już trzydzieści dziewięć ${ }^{71}$. Przy czym zauważyć należy, że dopiero w 1948 r. weszło w życie rozporządzenie Ministra Ziem Odzyskanych z 17 lutego 1948 r. w sprawie zakazu wywozu mienia ruchomego z obszaru tzw. Ziem Odzyskanych $^{72}$, wypełniające blankietową normę art. 44 m.k.k. Zatem zaznaczyć trzeba, że do 1948 r. wywóz mienia ruchomego z Ziem Odzyskanych nie był czynem karalnym. Takie stanowisko podzielał zarówno Sąd Okręgowy w Zielonej Górze, jak i Prokuratura Sądu Okręgowego w Zielonej Górze ${ }^{73}$.

W latach 1947-1948 odnotowano również znaczny wpływ spraw dewizowych i skarbowych. Za czyny te skazano sto jeden osób ${ }^{74}$. Niewielka była w omawianym okresie liczba spraw o przestępstwo odstępstwa od narodowości przewidziane w art. $1 \S 1$ dekretu z 28 czerwca 1946 r. o odpowiedzialno-

${ }^{67}$ Ibidem, k. [b.p.a.].

${ }^{68}$ Ibidem, k. [b.p.a.].

${ }^{69}$ Ibidem, k. [b.p.a.].

${ }^{70}$ Ibidem, k. [b.p.a.].

${ }^{71}$ Ibidem, k. [b.p.a.].

${ }^{72}$ Dz. U. 1948 r., nr. 11, poz. 82.

73 Pismo prezesa Sądu Okręgowego w Zielonej Górze do Prezesa Sądu Apelacyjnego w Poznaniu, sygn. akt AP ZG 89/433/5, k. [b.p.a.].

${ }^{74}$ Protokół trzeciej wizytacji Sądu Okręgowego w Zielonej Górze..., k.122. 
ści karnej za odstępstwo od narodowości w czasie wojny 1939-1945 roku ${ }^{75}$. Skazano bowiem tylko dziewięć osób za wspomniany powyżej czyn ${ }^{76}$. Jak się wydaje, było to spowodowane faktem, iż okręg sądowy obejmował jedynie tereny przynależące wcześniej do Niemiec.

Pewnym problemem był brak więzienia w okręgu Sądu Okręgowego w Zielonej Górze. Oskarżeni byli dowożeni na rozprawy z więzień oddalonych od Zielonej Góry o osiemdziesiąt do stu kilometrów ${ }^{77}$. Taka sytuacja powodowała częste odraczanie rozpraw z powodu niedowiezienia oskarżonego na termin rozprawy, co generowało również znaczne koszty konwojowania podsądnych.

Mniejsza była dynamika wpływu spraw cywilnych. W 1947 roku do repertorium „C" wpisano sto dziewięćdziesiąt trzy sprawy, przy czym ponad jedna trzecia stanowiły sprawy o rozwód, podobnie kwestia ta wyglądała w 1948 r. $^{78}$ Znaczna liczba spraw o rozwód była związana zapewne $\mathrm{z}$ dopiero co zakończoną wojną i rozpadem więzi międzyludzkich w trakcie jej trwania. Nie bez znaczenia mogło być również wejście w życie nowego prawa małżeńskiego. Dekret z 25 września 1946 r. o prawo małżeńskim ${ }^{79}$ przyjmował bowiem świecką formę małżeństwa. Z tego też względu sprawy rozwodowe należały do wyłącznej jurysdykcji sądów państwowych, a nie kościelnych ${ }^{80}$. Mimo, że w nowym prawie małżeńskim przyjęto zasadę trwałości małżeństwa, to jednak uzyskanie rozwodu stało się znacznie łatwiejsze niż miało to miejsce wcześniej, przede wszystkim na obszarach dawnego zaboru rosyjskiego ${ }^{81}$.

Funkcjonowanie Sądu Okręgowego w Zielonej Górze w pierwszych latach po zakończeniu drugiej wojny światowej stanowi przykład budowy struktur sądownictwa na obszarach wcześniej nienależących do państwa polskiego i charakteryzujących się nieco odmienną tradycją prawną, przynajmniej w odniesieniu do centralnych i wschodnich regionów Polski. Zauważyć trzeba, że struktury sądownictwa na tym obszarze od początku dostosowywano do podziału administracyjnego kraju. Okręg zielonogórskiego sądu okręgowego należał do właściwości miejscowej Sądu Apelacyjnego w Poznaniu. Zielona Góra i pozostałe miejscowości należące do właściwości terytorialnej sądu znajdowały się od 1946 roku w województwie poznańskim ${ }^{82}$. Także siedziby poszczególnych sądów grodzkich znajdowały się w miastach będących

75 Dz. U. 1946 r., nr 41, poz. 237.

76 Protokół trzeciej wizytacji Sądu Okręgowego w Zielonej Górze..., k.122

77 Ibidem, k. 122.

78 Ibidem, k. 114.

79 Dz. U. 1945 r., nr 48, poz. 270.

80 Z. Zarzycki, Rozwód w świetle akt Sadu Okręgowego w Krakowie w latach 1918-1945. Studium historyczno-prawne, Kraków 2010, s. 111.

81 Ibidem, s. 113.

$82 \S 3$ pkt. 3 rozporządzenia Rady Ministrów z dnia 29 maja 1946 r. w sprawie tymczasowego podziału administracyjnego Ziem Odzyskanych, Dz. U. 1946 r., nr 28, poz. 177. 
siedzibami powiatów ${ }^{83}$. Zapewne m.in. $\mathrm{z}$ tego względu nie utworzono Sądu Grodzkiego w Konotopie w miejsce funkcjonującego tam do 1945 r. niemieckiego sądu obwodowego.

Jak się wydaje, wraz z krzepnięciem struktur państwa polskiego Sąd Okręgowy w Zielonej Górze działał z coraz większą skutecznością. Świadczy o tym wzrost wpływu spraw cywilnych i karnych w następnych latach po zakończeniu wojny.

Nie bez znaczenia pozostaje również rola sądu jako elementu aparatu represji, a także organu służącego utrwalaniu nowej władzy. W tym kontekście należy wspomnieć nie tylko o upolitycznieniu kadr sędziowskich, wyrażającym się przede wszystkim w przynależności sędziów do partii politycznych, lecz również o działalności orzeczniczej zwłaszcza w sprawach o przestępstwa szczególnie niebezpieczne w okresie odbudowy państwa.

\section{BIBLIOGRAFIA}

\section{Opracowania}

Barcikowski W., Demokracja a sądownictwo, „Demokratyczny Przegląd Prawniczy", R. 1946, nr 5-6.

Chajn L., Na przełomie dwóch lat, „Demokratyczny Przegląd Prawniczy”, 1948, nr 1.

Dzwonkowski T., Powiat zielonogórski w latach 1945-1948. Zarys dziejów politycznych, Warszawa 1997.

Kurowska H., Liczba mieszkańców Zielonej Góry w latach 1945-2010, „Studia Zachodnie", 2013, t. 15.

Lityński A., Historia prawa Polski Ludowej, Warszawa 2005, s. 185.

Niestój H., Sąd obwodowy w strukturze sadownictwa niemieckiego. Ustrój sądów na Śląsku od czasów habsburskich do 1945 r. Struktury i zasady funkcjonowania sąu obwodowego. Problemy metodologiczne opracowania zespołów akt sąowych, „Archnet. Naukowy Portal Archiwalny” [dostęp 2.08.2015 r.].

Ozga-Świetlik E., Zarys Historii Lubuskiego Wymiaru Sprawiedliwości, „Studia Zielonogórskie", nr 11.

Zaradny R., Władza i społeczność Zielonej Góry w latach 1945-1975, Zielona Góra 2009.

Zarzycki Z., Rozwód w świetle akt Sąu Okręgowego w Krakowie w latach 1918-1945. Studium historyczno-prawne, Kraków 2010.

83 Powiaty krośnieński i gubiński utworzono na mocy rozporządzenia wojewody poznańskiego z 28 lipca 1945 r., W sprawie utworzenia powiatów krośnieńskiego i gubińskiego, „Dziennik Urzędowy Województwa Poznańskiego", 1945, nr. 5, s. 150. Siedzibami powiatów była również Zielona Góra i Świebodzin, por. §2 rozporządzenia Rady Ministrów z 29 maja 1946 roku w sprawie powołania ekspozytur urzędów wojewódzkich na obszarze Ziem Odzyskanych, Dz. U. 1946 r., nr 28, poz. 178 . 


\section{II. Źródła}

\section{A) Ustawodawstwo}

Gesetz, betreffend die Errichtung der Oberlandesgerichte und der Landgerichtevom 4. März 1878, „Gesetz-Sammlung für die Königlichen Preussischen Staaten”, 19. März, 1878, nr 12, s. 116.

Dekret z dnia 14 marca 1945 r. o zmianie prawa o ustroju sądów powszechnych, Dz. U. 1945 r., nr 9, poz. 46.

Dekret z dnia 16 listopada 1945 r. o postępowaniu doraźnym. Dz. U. 1945 r., nr 53, poz. 301 .

Dekret z dnia 22 lutego 1946 r. o rejestracji i przymusowym zatrudnianiu we władzach wymiaru sprawiedliwości osób, mających kwalifikacje do objęcia stanowiska sędziowskiego, Dz. U. 1946 r., nr 9, poz. 65.

Ustawa z dnia 27 kwietnia 1949 r. o zmianie przepisów postępowania karnego. Dz. U. z 1949 r., nr 32, poz. 238.

Rozporządzenie Rady Ministrów z 29 maja 1946 roku w sprawie powołania ekspozytur urzędów wojewódzkich na obszarze Ziem Odzyskanych, Dz. U. 1946 r., nr 28, poz. 178.

Rozporządzenie Rady Ministrów z dnia 29 maja 1946 r. w sprawie tymczasowego podziału administracyjnego Ziem Odzyskanych, Dz. U. 1946 r., nr 28, poz. 177.

Rozporządzenie Ministra Sprawiedliwości z 15 czerwca 1949 roku o utworzeniu Sądów Apelacyjnych w Białymstoku, Gdańsku, Kielcach, Łodzi, Olsztynie, Rzeszowie, Szczecinie i Wrocławiu oraz o ustaleniu okręgów Sądów Apelacyjnych, Dz. U. 1949 r., nr 36, poz. 270.

Rozporządzenie Ministra Sprawiedliwości z 6 lipca 1950 roku o utworzeniu Sądów Apelacyjnych w Koszalinie, Opolu i Zielonej Górze oraz o ustaleniu okręgów Sądów Apelacyjnych w Bydgoszczy, Katowicach, Kielcach, Łodzi, Olsztynie, Poznaniu i Warszawie, Dz. U. 1950 r., nr 28, poz. 265.

Okólnik Ministra Sprawiedliwości nr 50/NS.45 w sprawie kontaktu sq̨dów ze spoleczeństwem, „Dziennik Urzędowy Ministerstwa Sprawiedliwości”, 1945, nr 1.

Spis sądów i prokuratur Rzeczypospolitej, „Dziennik Urzędowy Ministerstwa Sprawiedliwości”, 1945, nr 1.

Rozporządzenie wojewody oznańskiego z 28 lipca 1945 r., w sprawie utworzenia powiatów krośnieńskiego i gubińskiego, „Dziennik Urzędowy Województwa Poznańskiego", 1945, nr 5.

\section{B) Zespół archiwalny Sądu Okręgowego w Zielonej Górze:}

Sprawozdanie Józefa Stachurskiego delegata do spraw organizacji sądownictwa polskiego w Zielonej Górze z 12.08.1945 r., Archiwum Państwowe w Zielonej Górze [dalej jako AP ZG], sygn. Akt 89/433/24, k. 2.

Sprawozdanie sędziego Stachurskiego do sędziego Sądu Apelacyjnego w Poznaniu T. Krycha z 12.08.1945 r., AP ZG, sygn. Akt 89/433/24, k. 2.

Protokół wizytacji Sądu Okręgowego w Zielonej Górze przeprowadzonej w dniach 20.05.-25.05.1946 r. przez sędziego sądu apelacyjnego W. Słonimskiego na po- 
lecenie prezesa Sądu Apelacyjnego w Poznaniu, AP ZG, sygn. Akt 89/433/28, k. 2.

Pismo p.o. prezesa Sądu Okręgowego w Zielonej Górze S. Matczyńskiego do ministerstwa sprawiedliwości z 7.08.1946 r., sygn. akt AP ZG 89/433/24, k. 55.

Pismo p.o. prezesa Sądu Okręgowego w Zielonej Górze do prezesa Sądu Apelacyjnego w Poznaniu z 9 września 1946 roku, sygn. akt AP ZG 89/433/28, k. 17.

Protokół drugiej wizytacji Sądu Okręgowego w Zielonej Górze przeprowadzonej w dniach 2-7 czerwca 1947 roku przez sędziego Sądu Apelacyjnego w Poznaniu W. Słonimskiego, sygn.. akt AP ZG 89/433/28, k. 25.

Pismo kierownika Sądu Grodzkiego w Krośnie Odrzańskim do Prezesa Sądu Okręgowego w Zielonej Górze z 16.08.1947 r., AP ZG, sygn. Akt 89/433/24, k. 168.

Protokół trzeciej wizytacji Sądu Okręgowego w Zielonej Górze przeprowadzonej w dniach 2-5 listopada 1948 roku, sygn. akt AP ZG 89/433/28, k. 89.

Pismo prezesa Sądu Okręgowego w Zielonej Górze do Prezesa Sądu Apelacyjnego w Poznaniu, sygn. akt AP ZG 89/433/5, k. [b.p.a.].

\section{C) Inne:}

Powszechny sumaryczny spis ludności z dnia 14 lutego 1946 r., Warszawa 1947, tabela nr 3, s. 51 .

\section{DIFFICULT BEGINNINGS. \\ THE ORGANIZATION OF THE REGIONAL COURT IN ZIELONA GORA IN THE FIRST YEARS AFTER THE END OF WORLD WAR II}

\section{Summary}

After the end of World War II, the Polish government started to organize the courts on the so-called Recovered Territories (former German territories which were joined to Poland). An example of the organization of Polish courts on the so-called Recovered Territories is the Regional Court in Zielona Gora.

This court began its functioning in the second part of 1945. At the beginning, it was a very small court. It consisted of only two departments: civil and penal. However, in the following years, this structure was developed significantly and already in 1948 the Regional Court in Zielona Góra consisted of five departments. In the first two years, after the end of war, the influence of cases upon the Regional Court in Zielona Góra was not high. However, there was a significant increase in the influence of criminal and civil cases since 1947. Undoubtedly, this was due to the solidifying of structures of the Polish judiciary on the so-called Recovered Territories. 


\title{
LES DÉBUTS DIFFICILES. \\ L'ORGANISATION DU TRIBUNAL DE LA CIRCONSCRIPTION DE ZIELONA GÓRA DANS LES PREMIÈRES ANNÉES APRÈS LA SECONDE GUERRE MONDIALE
}

\begin{abstract}
Résumé
Après la Seconde Guerre mondiale, les autorités polonaises ont commencé à organiser les institutions et les structures de la justice polonaise dans la région surnommée les Territoires Récupérés. L'un des exemples de ce genre d'action est la création du Tribunal de la circonscription de Zielona Góra.

Ce tribunal a commencé à fonctionner dans la seconde moitié de 1945. Initialement, il était un petit tribunal, composé de deux départements: pénal et civil. La structure organisationnelle du Tribunal de Zielona Góra a subi un développement progressif, et en 1948, il y fonctionnait cinq départements, nota bene : la plupart des départements s'occupaient des affaires criminelles. Dans la période juste aprèsguerre, peu d'affaires ont été introduites devant le tribunal, cependant, depuis 1947, on a noté l'augmentation du nombre d'affaires aussi bien civiles que pénales. Sans aucun doute, ce phénomène découlait de la solidification des structures du système judiciaire polonais sur les soi-disant Territoires Récupérés.
\end{abstract}

